\title{
Severe Methanol Poisoning with Supralethal Serum Formate Concentration: A Case Report
}

\author{
Olga Nurieva Katerina Kotikova \\ Department of Occupational Medicine, Toxicological Information Center, First Faculty of Medicine, \\ Charles University in Prague and General University Hospital, Prague 2, Czech Republic
}

\section{Key Words}

Acute methanol poisoning · Formic acid · Long-term sequelae

\begin{abstract}
Objective: To present a case of survival without visual and central nervous system sequelae at a formate concentration of twice the reported lethal level. Clinical Presentation and Intervention: This was a case of a 33-year-old man who ingested 1 liter of a toxic mixture of methanol and ethanol. Upon admission, he presented with anxiety, tachycardia and hypertension and had a serum formate level of 1,400 mg/l (normal range $0.9-2.1 \mathrm{mg} / \mathrm{l}$ ), a methanol level of $806 \mathrm{mg} / \mathrm{l}$ (normal range 2-30 mg/l), an undetectable ethanol concentration and a normal lactate level. A $10 \%$ solution of ethanol and folinic acid was administered intravenously and two 8-hour sessions of intermittent hemodialysis were performed. The patient was discharged on the fifth day without sequelae of poisoning. The follow-up examinations 3 months and 2 years later revealed no damage to the basal ganglia. The patient had normal visual-evoked potential and findings on optical coherence tomography. The genetic analysis revealed a rare minor allele for the gene coding
\end{abstract}

$\mathrm{CYP}_{2} \mathrm{E}_{1}$ enzyme of the microsomal ethanol oxidizing system. Conclusion: The patient survived acute methanol poisoning without long-term sequelae despite a high serum level of formic acid upon admission.

(c) 2015 S. Karger AG, Basel

\section{Introduction}

Acute methanol poisonings in the case of mass outbreaks, when health care resources are limited or overwhelmed, are characterized by high mortality rates and severe health sequelae in the survivors, despite significant progress in diagnostics and treatment [1]. Methanol poisoning may occur either intentionally through abuse or attempted suicide or else unintentionally through misuse or accidents. Metabolic conversion of methanol leads to the accumulation of formic acid inhibiting cytochrome $\mathrm{C}$ oxidase in mitochondria, which then results in severe acidosis, visual impairment and damage to the basal ganglia $[2,3]$.

The treatment consists of early administration of antidotes, fomepizole or ethanol to block alcohol dehydrogenase, alkalization with a buffer, hemodialysis and folate

\begin{tabular}{ll}
\hline KARGER 125/s & $\begin{array}{l}\text { ○ 2015 S. Karger AG, Basel } \\
1011-7571 / 15 / 0246-0581 \$ 39.50 / 0 \quad \text { Karger }\end{array}$ \\
E-Mail karger@karger.com & $\begin{array}{l}\text { This is an Open Access article licensed under the terms of the } \\
\text { Creative Commons Attribution-NonCommercial 3.0 Un- } \\
\text { ported license (CC BY-NC) (www.karger.com/OA-license), } \\
\text { applicable to the online version of the article only. Distribu- } \\
\text { tion permitted for non-commercial purposes only. }\end{array}$
\end{tabular}

Olga Nurieva, MD

Department of Occupational Medicine, Toxicological Information Center First Faculty of Medicine, Charles University in Prague and General University Hospital Na Bojisti 1, CZ-120 00 Prague 2 (Czech Republic)

E-Mail olganurieva@seznam.cz 
substitution [4-6]. Despite intensive treatment, the hospital mortality rate is higher than $20 \%$, and the health sequelae of poisoning can be present in $40 \%$ of survivors [1]. We present a case of severe methanol poisoning with a supralethal serum formate concentration and follow-up clinical examinations 3 months and then 2 years after the poisoning.

\section{Case Report}

Over 3 consecutive days in October 2012, a 33-year-old male weighing $102 \mathrm{~kg}$ consumed 1 liter of vodka containing a mixture of methanol and ethanol at a 50/50 proportion, with a total alcohol content of approximately $40 \%$ volume. The patient also admitted to coingestion of beer, but no other strong drink or wine. He did not notice any symptoms besides common inebriation during these three days. On the fourth day, he was informed by a family member that 3 other people who consumed the same drink bought from the same dealer had been hospitalized, and that 1 had died. The patient visited the Emergency Department of Medicine the same day at 3 p.m. and confessed to the ingestion of the toxic spirits in the last 3 days.

Upon admission to the intensive care unit, the patient had an extremely high serum formate concentration of $1,400 \mathrm{mg} / \mathrm{l}$ or 30.4 $\mathrm{mmol} / \mathrm{l}$ (normal range $0.9-2.1 \mathrm{mg} / \mathrm{l}$ or $19.5-46.1 \mu \mathrm{mol} / \mathrm{l}$ ), a serum methanol level of $806 \mathrm{mg} / \mathrm{l}$ or $25.2 \mathrm{mmol} / \mathrm{l}$ (normal range $2-30 \mathrm{mg} / \mathrm{l}$ or $0.06-0.94 \mathrm{mmol} / \mathrm{l}$ ) and a urine formate level of $392 \mathrm{mg} / \mathrm{l}$ or 8.5 $\mathrm{mmol} / \mathrm{l}$ (normally not detected in urine). His serum ethanol was negative and he had only mild acidosis (arterial blood pH 7.28, bicarbonate $15.6 \mathrm{mmol} / \mathrm{l}, \mathrm{pCO}_{2} 3.78 \mathrm{kPa}$, base deficit $-8.0 \mathrm{mmol} / \mathrm{l}$ and anion gap $-23.0 \mathrm{mmol} / \mathrm{l})$. Formate was measured enzymatically using formate dehydrogenase and nicotinamide adenine dinucleotide. The patient had minor hyperglycemia $(6.7 \mathrm{mmol} / \mathrm{l})$ as well as normal levels of urea $(3.4 \mathrm{mmol} / \mathrm{l})$, creatinine $(64 \mu \mathrm{mol} / \mathrm{l})$ and lactate $(1.7$ $\mathrm{mmol} / \mathrm{l})$. He had a heart rate of 110 beats $/ \mathrm{min}$, a blood pressure of $180 / 100 \mathrm{~mm} \mathrm{Hg}$, a respiratory rate of 24 breaths/min and a score of 15 on the Glasgow Coma Scale. He had no symptoms of visual toxicity and admitted only experiencing anxiety due to the fear of death.

The patient was given a $10 \%$ ethanol solution intravenously immediately after admission to achieve the protective serum ethanol concentration of $1,000-1,500 \mathrm{mg} / \mathrm{l}(22-33 \mathrm{mmol} / \mathrm{l})$. As there was limited availability of fomepizole as a first-choice antidote for methanol poisoning (prioritized for patients with arterial blood $\mathrm{pH} \leq 7.0)$, he was also given folinic acid ( $20 \mathrm{ml}$ calcium folinate, 10 $\mathrm{mg} / \mathrm{ml}$; Hospira UK Ltd., UK) to substitute the inner pool of folate. Intermittent hemodialysis (IHD) was performed for $8 \mathrm{~h}$ to eliminate the formate and methanol. We used a dialyzer Fresenius F4008S, a polysulfone filter with membrane surface $1.6 \mathrm{~m}^{2}$, a dialysate solution BIC 315 containing $32.6 \mathrm{mmol} / \mathrm{l}$ of bicarbonate, heparin anticoagulation, with a blood flow rate of $220 \mathrm{ml} / \mathrm{min}$, a dialysate flow rate of $500 \mathrm{ml} / \mathrm{min}$ and no complications during the dialysis session. At 5 a.m. the next day, the serum methanol value was $254 \mathrm{mg} / \mathrm{l}(7.9 \mathrm{mmol} / \mathrm{l})$, serum ethanol was $1,000 \mathrm{mg} / \mathrm{l}(22$ $\mathrm{mmol} / \mathrm{l}$ ) and the serum formate was negative; the second set of 8-hour IHD was done to eliminate the remaining serum methanol completely. The patient was discharged on the fifth day after admission without health sequelae of poisoning.

\section{Follow-Up}

The follow-up clinical examination 3 months later included a complete ocular examination with standard ophthalmic tests, optical coherence tomography, visual evoked potentials and magnetic resonance imaging of the brain to estimate the nature and dynamics of long-term visual and central nervous system sequelae. The patient had an elevated carbohydrate-deficient transferrin level of $2.5 \%$ and a positive urine ethyl glucuronide screening test, suggesting chronic alcohol consumption. The biochemical parameters, including hepatic tests, prealbumin, vitamin $B_{12}$, thyroid-stimulating hormone, glucose, renal tests, electrolytes, cholesterol and lipids, were normal. A genetic analysis of the blood sample revealed the presence of a rare minor allele gene coding cytochrome P450 $2 \mathrm{E} 1\left(\mathrm{CYP}_{2} \mathrm{E}_{1}\right)$ enzyme for the microsomal ethanol-oxidizing system.

The ophthalmological examination showed that the patient had a visual acuity of $6 / 6$ in both eyes, normal color vision and perimeter and contrast sensitivity. In addition, there were normal findings on the fundoscopy, with reddish clear-cut optic discs. On optical coherence tomography, the retinal nerve fiber layer was normal bilaterally. In the pattern-reversal visual evoked potentials, there was a normal evoked complex elicited by the stimulation of either eye, with borderline latency of the P100 wave for the right eye. On $\mathrm{T}_{2}$-weighted MRI, the gradient sequence 'Fast Field Echo' did not revealed any damage to the basal ganglia and other parts of brain. The neurological examination, including electromyography, did not reveal any pathology. At the second follow-up clinical examination 2 years after the poisoning, conducted using the same protocol in the same hospital, no long-term visual and central nervous system sequelae of severe methanol poisoning with supralethal serum formate concentration were present.

\section{Discussion}

This was a case of a patient who consumed an excessive mixture of methanol and ethanol with a serum formate concentration almost 3 times higher than the concentration commonly associated with severe visual impairment and basal ganglia damage [7]. However, the patient survived the acute methanol poisoning without long-term sequelae.

Several factors could explain this favorable outcome of methanol poisoning. First, an intermittent mode of hemodialysis was used, rather than a continuous one. The mean elimination half-life of formate in IHD is 2.2 times shorter than the continuous venovenous hemodialysis or hemodiafiltration [3]. The shorter mean elimination halflife of formate during IHD is due to the higher dialysate and blood flow rates [3]. Based on the mean elimination half-life of formate when using IHD, after $4-5 \mathrm{~h}$, the patient had a serum formate concentration that was under the toxic level of $4 \mathrm{mmol} / \mathrm{l}$. This is in contrast to the continuous mode of hemodialysis, where the toxic level of formic acid in the blood would be maintained for $>10 \mathrm{~h}$. 
According to the current recommendations for extracorporeal treatment, IHD is the modality of choice in the management of acute methanol poisoning [8].

Second, the genetic analysis showed the presence of a rare minor allele for the gene coding $\mathrm{CYP}_{2} \mathrm{E}_{1}$ enzyme of the microsomal ethanol oxidizing system. The inducible hepatic microsomal ethanol oxidizing system is able to metabolize significant amounts of ethanol and methanol upon consumption (about 10\%). The activity of this system is strongly increased in individuals who drink regularly (long-term ethanol abuse). According to the study of Hubacek et al. [9], the minor alleles of this gene may represent certain protective predispositions towards alleviating the inhibitory effect of formic acid on mitochondrial cytochrome $\mathrm{C}$ oxidase, preventing severe lactate acidosis in patients with high serum levels of formate. The toxic effect of formic acid on the optic nerve depends on the degree of acidemia, because only the undissociated formic acid can cross the membrane. The dissociation constant of formic acid ( $\mathrm{pKa}$ ) is 3.75 , i.e. a $\mathrm{pH}$ drop of 0.3 caused by hyperlactacidemia would mean doubling the undissociated formic acid levels, hence a significant increase in ocular toxicity.

Finally, regular ingestion of a toxic mixture of methanol and ethanol over the course of several days with coingestion of beer could have helped to consistently maintain a positive serum ethanol level for most of the time [1, 10] before the patient presented to the hospital. The remaining subtherapeutic concentrations of serum ethanol would apparently be sufficient to effectively block the alcohol dehydrogenase enzyme. The target level of 22 $\mathrm{mmol} / \mathrm{l}(1,000 \mathrm{mg} / \mathrm{l})$ for serum ethanol is not evidencebased and the therapeutic level may actually be lower [10]. This suggestion raises the issue of a possible protective effect of prehospital administration of ethanol by medical/paramedic staff in ambulances, and even self-administration of ethanol before a definite diagnosis is made for cases suspicious for acute methanol poisoning.

\section{Conclusion}

In acute methanol poisonings, survival without longterm health sequelae is possible, even in patients with extremely high serum formate concentrations upon admission. Factors associated with favorable outcomes need further study.

\section{Acknowledgements}

This study was supported by the Projects of the Charles University in Prague P25/1LF/2 and P28/1LF/6, and the Project of the Ministry of Health of the Czech Republic 9/15/NAP.

\section{Disclosure Statement}

There were no conflicts of interest.

\section{References}

1 Zakharov S, Pelclova D, Urban P, et al: Czech mass methanol outbreak 2012: epidemiology, challenges and clinical features. Clin Toxicol 2014;52:1013-1024.

2 Liesivuori J, Savolainen H: Methanol and formic-acid toxicity - biochemical-mechanisms. Pharmacol Toxicol 1991;69:157-163.

3 Zakharov S, Pelclova D, Navratil T, et al: Methanol and formate elimination half-life during treatment for methanol poisoning: intermittent haemodialysis vs. continuous haemodialysis/haemodiafiltration. Kidney Int 2014;86:199-207.

-4 Barceloux DG, Bond GR, Krenzelok EP, et al: American Academy of Clinical Toxicology practice guidelines on the treatment of methanol poisoning. J Toxicol Clin Toxicol 2002; 40:415-446.
Zakharov S, Nurieva O, Navratil T, et al: Acute methanol poisonings: folates administration and visual sequelae. J Appl Biomed 2014;12:309-316.

6 Zakharov S, Navratil T, Pelclova D: Fomepizole in the treatment of acute methanol poisonings: experience from the Czech mass methanol outbreak 2012-2013. Biomed Pap Med Fac Univ Palacky Olomouc Czech Repub 2014;158:641-649.

7 Zakharov S, Kurcova I, Navratil T, et al: Is the measurement of serum formate concentration useful in the diagnostics of acute methanol poisoning? A prospective study of $38 \mathrm{pa}-$ tients. Basic Clin Pharmacol Toxicol 2015; 116:445-451. $\checkmark 8$ Roberts DM, Yates C, Megarbane B, et al: Recommendations for the role of extracorporeal treatments in the management of acute methanol poisoning: a systematic review and consensus statement. Crit Care Med 2015;43: 461-472.

-9 Hubacek JA, Pelclova D, Seidl Z, et al: Rare alleles within the CYP2E1 (MEOS System) could be associated with better short-term health outcome after acute methanol poisoning. Basic Clin Pharmacol Toxicol 2015;116: 168-172.

10 Roy M, Bailey B, Chalut D, et al: What are the adverse effects of ethanol used as an antidote in the treatment of suspected methanol poisoning in children? J Toxicol Clin Toxicol 2003;41:155-161. 